\section{Determinants of customer experience in e-services: the case of online universities}

\author{
Alicia Izquierdo-Yusta ${ }^{1}$ \\ Ana I. Jimenez-Zarco ${ }^{2}$ \\ Maria Pilar Martinez-Ruiz ${ }^{3}$ (D) \\ Inés Gonzalez-Gonzalez ${ }^{4}$ (iD)
}

\begin{abstract}
Purpose - The study analyzes the key drivers of consumer experience in e-services, with the particular goal of defining and quantifying the influence of website quality and university brand assessments on the experience of consumers who are students of a virtual university.
\end{abstract}

Theoretical framework - To carry out the research we analyzed website quality, brand, and customer experience

Design/methodology/approach - We carried out a statistical analysis using structural equation modeling of web-based questionnaires collected from 306 postgraduate students of a virtual university.

Findings - Our research reveals that the university's brand is the most influential factor. In contrast, the influence exerted by the web environment is lower. Of the three website dimensions, the quality of the system exerts the greatest influence, followed by relationship quality, which is moderated by the role of university staff.

Research, practical, and social implications - We propose that the quality of a virtual classroom (quality of the system, quality of information, and service quality), together with students' individual assessments of the brand, determine the students' experience as consumers of this service. The brand assessment is the most important factor.

Keywords - Student experience, website quality, brand assessment, virtual learning environment, virtual universities

1. University of Burgos, Economics and Business Faculty, Department of Economics and Business Administration, Burgos, Spain

2. Open University of Catalonia, Economics and Business Faculty, Department Innovation and Marketing, Barcelona, Spain

3. University of Castilla la Mancha, Department of Economics and Business Administration, Albacete, Spain

4. International University of La Rioja, Business and Communications Faculty, Department of Business, Logroño, Spain

How to cite:

Izquierdo-Yusta, A., Jimenez-Zarco, A., Martinez-Ruiz, M., Gonzalez-Gonzalez, I. (2021). Determinants of customer experience in e-services: the case of online universities. Revista Brasileira de Gestão de Negócios, 23(1), p.1-20.
Received on:

03/14/2019

Approved on:

07/27/2020

Responsible Editor:

Prof. Dr. Guilherme Shiraishi

Evaluation process:

Double Blind Review

Reviewers:

Jana Majerova; Hector Hugo PérezVillarreal; Lucas Lira Finoti.

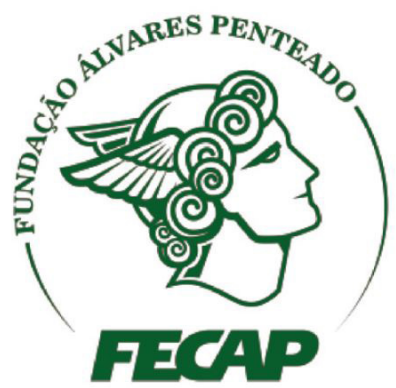

Revista Brasileira de Gestáo de Negócios

https://doi.org/10.7819/rbgn.v23i1.4097 


\section{Introduction}

The intensive use of information and communication technologies (ICT) has revolutionized university education, in terms of both its operations and the strategic orientation that defines its management. For example, new models of the teaching-learning process have redefined the roles of teachers and students, as well as the relationship between them (Elsharnouby, 2015; González-Marcos, Alba-Elías, Navaridas-Nalda, \& Ordieres-Meré, 2016; Park, 2019; Pimienta, Barzola, \& Zurdo, 2016). Furthermore, ICT have modified the environment in which this relationship develops, favoring the emergence of virtual learning environments and new teaching resources (Cassidy, 2016). Finally, ICT have made it possible for universities to attract a global market of potential consumers and competitors. Accordingly, we can observe notable changes in the strategic and management models developed by universities (Pucciarelli \& Kaplan, 2016).

As opposed to the traditional model, where the university had a social and public role as a creator and transmitter of knowledge, favoring the development of the territory, a new vision has emerged (Peters \& Besley, 2006). Here the university is an economic agent that seeks financial profitability, is concerned with its image, and competes in a global environment with other higher education institutions (Aleixo, Leal, \& Azeiteiro, 2018; Altbach, Reisberg, \& Rumbley, 2019). To survive and consolidate their positions, universities increasingly adopt a stakeholder orientation, in which the student, as the consumer of the academic services provided, represents the center of university activity (González-Marcos et al., 2016). This growing orientation has also meant an understanding of student satisfaction is fundamental for university management (Datu \& Mateo, 2015). It is the students who enable educational institutions to exist and endure, so their satisfaction is a primary consideration and should reduce their likelihood of leaving or changing universities.

Traditional methods for achieving customer satisfaction relied on marketing strategies; today, the emphasis has shifted toward achieving emotional links with consumers, especially based on their experience. Iglesias, Markovic, and Rialp (2019) highlight important differences between customer satisfaction and experience. Satisfaction is more objective and relates directly to outcomes, whereas experience is more subjective and pertains to both the results obtained and the process that enables those outcomes to be achieved (Shapiro et al., 2017; Srivastava \& Koul, 2016). Thus, a customer may be satisfied with the final result but still have suffered an unpleasant experience in the process. Moreover, simple satisfaction does not create links between the customer and the brand. It is only when the customer feels emotionally attached to the brand that loyalty levels increase (Fernandes \& Moreira, 2019).

In a university context, the students' experience is a key determinant of the success of the institution (Shapiro et al., 2017). Cerezo, Sánchez-Santillán, PauleRuiz, and Núnez (2016) point out that education is a service, where there are strong and long-term interaction processes - through teaching and learning, among others - between the students and the institution. However, in virtual learning environments, this situation is more evident due to the students not only interacting with the teachers and other students, but also with the virtual space and the learning resources as well (Vuopala, Hyvönen, \& Järvelä, 2016). Nowadays, a significant part of teaching activity takes place in virtual environments and universities also need to consider how the student's virtual experience is conditioned by this context surrounding the learning process.

Accordingly, we seek to analyze the determinants of a student's experience in an online university environment. We start with the concept of customer experience, which we apply in the context of online university services. A model proposed by Schmitt and Zarantenello (2013) and Shapiro et al. (2017) serves as the foundation for establishing our prediction that the quality of the virtual classroom and brand assessments are primary determinants of online university students' experience. To test our hypotheses, we investigate responses from a sample of students of the one digital university in Spain. The findings confirm the validity of the model, showing that the focal factors have positive effects on university students' experience. We find evidence of the importance of the quality of the website, as well as the name of the university, in the student's experience. This highlights the need for university managers to be aware of the need not only to adapt their service offerings to customer needs but also to consider the importance of the environment in which they are located when determining the customer experience and the degree of satisfaction obtained. 


\section{Literature Review}

The emotional bonds of a customer with a brand or company offer important indicators of business success (Iglesias et al., 2019). As Tukker and Tischner (2017) warn, quality products or services are no longer enough to ensure competitiveness or firm survival. Some studies even question if customer satisfaction leads to loyalty (Atulkar \& Kesari, 2017; Leckie, Nyadzayo, \& Johnson, 2016) or recommendation intentions (Beyari \& Abareshi, 2018).

Such issues are particularly pertinent in complex, rapidly changing environments, such as those that most companies face today. Businesses operate in mature, highly competitive markets, often with almost undifferentiated products and services, such that many companies opt for essentially price-based positions (Andersson, Awuah, Aagerup, \& Wictor, 2020). Customers are also more demanding, better informed, and interested in customized products. Thus, a strategic change in the existing paradigm means customers not only want to meet their basic needs but also reach a higher level in their purchasing and consumption processes, defined by emotions and experiences (Jiménez-Zarco, Rospigliosi, Martínez-Ruiz, \& Izquierdo-Yusta; 2019).

At the same time, ICT developments have produced new competitive contexts that have opened the door to new environments marked by collaboration, dialogue, and close relationships among different agents. The customer thus has a more direct and active role concerning the brand (Gómez-Suárez, Martínez-Ruiz, \& Martínez-Caraballo, 2017). This relationship can be continued over time, thereby increasing the number of interactions and experiences consumers have during their journey (Riivits-Arkonsuo, Kaljund, \& Leppiman, 2015). To strengthen its relationship with customers, a company must thus monitor the whole set of experiences they have, as well as identifying and managing the factors that determine them so that it can establish marketing policies to ensure a positive overall customer experience.

\section{I Customer experience: determinants and consequences}

Jain, Aagja, and Bagdare (2017) define customer experience as the internal, integral, subjective response or reaction of the customer to any direct or indirect contact with a company or brand. Its psychological nature is evidenced in the works of Chathoth et al. (2014) and Lemon and Verhoef (2016), which indicate that this strictly personal experience prompts the customer's involvement at different levels: sensory, emotional, cognitive, physical, and relational (Garg, Vandana, \& Kumar, 2017). Its evaluation depends on a comparison between the customer's expectations and the stimuli that emerge from the interaction with the company and its offering at different moments of contact (Ebrahim, Ghoneim, Irani, \& Fan, 2016). Finally, consumer experiences can be direct and indirect, and can also vary in strength and intensity, so certain experiences are stronger or more intense than others (Lemon \& Verhoef, 2016). They also differ in valence, so some experiences are more positive and others are more negative.

According to Farias, Aguiar, and Melo, (2014), in consumption contexts, especially of services, the experience depends on the expectations and the interactions that the customer establishes with the brand. As a result of that experience, the customer may undergo changes in what he or she thinks, feels, and how he or she acts toward the brand (Kahn, Inman, \& Verhoef, 2018). Munoz-Arcentales, Montoya, Chalen, and Velásquez (2018) and Schmitt and Zarantenello (2013) concur that the consumption experience depends on several factors, including not only use and practice but also the habit or custom that a customer develops regarding the product or service. Current use of a brand directly connects the experience with perceptions, feelings, and direct observations stemming from the interaction (Wei, Torres, \& Hua, 2016). As a consequence, the relationship is influenced by the touchpoints between the consumer and the company, which involve both the environment in which it takes place (physical or virtual) and the people engaged in the interaction (employees who provide the service) (Zomerdijk \& Voss, 2010). As a customer uses a product or service, he or she gains more experience. The second factor, pertaining to habits or customs, refers to the shared past between the customer and the brand, marked by knowledge, feelings, and varying levels of loyalty over time (Lemon \& Verhoef, 2016). This factor is determined by the brand's ability to fulfill its promises to the customer, which should increase the degree of commitment it acquires from that customer.

Furthermore, it defines the meaning of the brand for the customer, which creates expectations (Esch et al., 2012). Finally, Blackston and Lebar (2015) point out that a positive or negative experience is determined by the customer's interpretation of all sensory information received during the interaction, as well as the expectations 
that he or she had for the relationship with the brand or company. These perceptions are stored in long-term memory (Carbone \& Haeckel, 1994) and thus affect customer behavior over time, with important practical implications for brands, whether they operate in offline or online environments.

Identifying the main effects of experience on consumer behavior has become the focus of interest of academics and professionals. Pine and Gilmore (1998) provide evidence that companies' key competitiveness resides in providing consumers unique experiences and unforgettable memories. Thus, companies strive for consumers to obtain not only positive or satisfactory but also memorable experiences (Iglesias et al., 2019). Experiential marketing recognizes that consumer interest is not restricted to purely functional benefits, but also extends to the consumption of the total experience (Smilansky, 2017). However and Adhikari (2019) provide evidence that the experience can engage the consumers' senses of sight, hearing, touch, and feeling in an unforgettable way.

Ahn and Back (2018) show that a memorable experience generates short-term behavioral change and builds an emotional connection and a profound relationship with the brand, ultimately leading to a rational response to the brand and product purchase. Along the same lines, Tsaur, Chiu, and Wang (2006) find evidence that experience has a positive effect on emotions and, subsequently, on behavioral intention through the mechanism of satisfaction.

Satisfaction is confirmed as one of the first results of experience (Ali, Amin, \& Cobanoglu, 2016), and is defined in terms of the pleasure (Wang, 2011) and enjoyment (Sina \& Kim, 2019) felt by the customer as a direct consequence of the result obtained. However, in the services sector, the end value provided by a service is determined by the way in which the service is offered; in other words, by how the interaction between the customer and the brand is conducted (Ali et al., 2018). Thus, the inseparability of the production and consumption of digital services conditions the result of the interaction and its capacity to deliver value and, therefore, the customer's experience (Vargo \& Lusch, 2014).

\subsection{Customer experiences in an online university context}

The concept of experience is also consistent with current marketing approaches, such as the service- dominant logic (Vargo \& Lusch, 2017) and the notion of perceived value (Yachin, 2018). In these views, the purchase and use of a product offer consumers different kinds of value. The consumer obtains functional value according to the product's attributes, but value also lies in the hedonic and experiential elements surrounding the product and services, and in the experience of creating and of consumption itself (Yachin, 2018). In other words, customers assess the value perceived and actively participate in its creation (Merz, Zarantonello, \& Grappi, 2018).

Customer perceptions and expectations about a brand or company are central in the definition and assessment of value. The result depends on which services and resources the organization uses and the way it addresses the relationship process with its customers. Furthermore, the outcome is influenced by the organization's ability to meet customer expectations and goals (Smith, 2019).

A wide range of studies analyze the use of value in different services, such as tourism and hospitality (Gallarza, Arteaga, \& Gil-Saura, 2019), telecommunications (Izogo, 2017), retail (Kim, Matsui, Park, \& Okutani, 2019), and financial services (Dootson, Beatson, \& Drennan, 2016). However, competitive pressures have grown in other service sectors, too, such as health care (Lakdawalla et al., 2018), public services (Osborne, 2018), and education (Botti, Grimaldi, Tommasetti, Troisi, \& Vesci, 2017). Therefore, it is increasingly necessary to analyze these concepts with regards to other types of services. In particular, Spanish universities have not escaped the reality in which reduced public investments force academic institutions to develop management-based models and self-financing options. At the same time, academic fees continue to increase (Mahdi, Nassar, \& Almsafir, 2019), while students can find learning and research opportunities anywhere in the world. Therefore, considering the increased competition among universities (Dixon et al., 2015), it is not surprising that the student experience has emerged as a highly relevant variable in university management models (Marris, 2018)

From a marketing perspective, students are the consumers of all the services offered by universities. The European Higher Education Area (EHEA) emphasizes value-based evaluations and questions related to student perceptions and experiences in the classroom (GonzálezMarcos et al., 2015). This experiential educational context, which involves the consumption of services (Shaw, 2018), is highly complex, especially when it is offered online, featuring high levels of interactivity and change, which 
in turn encourage the creation of experiences (Smilansky, 2017).

Students' experiences can be understood as the result of the totality of their interactions with an educational institution. Following González-Rodríguez, Domínguez-Quintero and Paddison (2019), Shapiro et al., (2017), and Schmitt and Zarantenello (2013), we posit that students' experiences are determined by the knowledge and interactions that each student has about and with the institution, as well as the context in which the relationship develops.

According to these authors, interactions can occur either before or after the purchase and consumption processes. Thus, how students perceive and process the institution's attributes and characteristics in verbal, visual, and multisensorial form, as well as how they form judgments, attitudes, preferences, etc., influence their experience with the institution (Lewis 2018). Also, interaction can be direct or indirect, depending on whether the student's contact with the institution is direct or mediated by another agent, which influences the results of the interaction. The use of virtual learning environments makes it possible for students to have virtual experiences, where technology plays a mediator role (Moorhouse, Dieck, \& Jung, 2018).

Furthermore, student-institution interactions always change over time, according to both the relationship's maturation time, as well as the evolution, changes, and innovations that organizations can introduce over time (Bryson, 2018). In the early phases of the relationship, the parties do not know each other; but as time passes, the relationship becomes habitual and marked by increased knowledge. The relationship may even be based on trust and commitment because the members have demonstrated their ability to fulfill promises (Hansen, Gronholdt, Josiassen, \& Martensen, 2016). A satisfactory relationship between the student and the institution constitutes the basis for an optimal customer experience (Bishop, 2018). On the other hand, universities face the challenge of providing virtual learning environments where the students can relate with each other, besides accessing the organizational and learning resources (Goeser, Hamza-Lup, Johnson, \& Scharfer, 2011).

In today's digital world, universities have of an increasing range of new media at their disposal that create new students' online experiences before and after their purchase. In this context, it is important to understand what elements influence the creation of experience, as well as how website design affects the experience that the student can have (Tsay et al., 2018).

Schmitt and Zarantenello (2013) identify four important themes based on a review of the existing literature on digital environments that could be applied to the digital university context. First, online environments present a stage for identity building and identity play, where consumers use brands to represent themselves online (Bowen \& Bowen, 2019). Second, online experiences are often tied to non-physical consumption and virtual products and services, leading to a growing dematerialization of objects and commodities (Boustani, 2019). Third, relationships among consumers are growing, facilitated by the fast increase in user-generated content; as consumers interact in their own networks, their relationship with brands changes (Liu, Burns, \& Hou, 2017). Finally, the social landscape of consumers is changing as a result of social networking sites and the intersection of offline and online reality. This changes consumers' self-presentation, impression management, friendship building, and relationship management (Frantz, Pears, Vaughn, Ferrell, \& Dudley, 2016).

Universities' names have become in a truly digital brand, used as a strategic asset that reflects the institution's quality, influence, and trustworthiness. They have a significant impact on the student decisionmaking process. Due to the connotations associated with the brand, students can obtain a first impression of the university, which facilitates their decision about whether to study there. On the other hand, students' experiences are often tied to the characteristics and potentialities of the digital environment. In this sense, digital learning environment quality is key, due to it not only allowing for the incorporation of a wide range of tools and resources that make the teaching-learning process possible, but it also allowing relationships and dialogue with other individuals, especially university staff and other students.

Figure 1 presents our proposed conceptual model for the online university student experience. That is, the student's experience comprises the quality of the virtual learning environment and assessments about the brand of the digital university.

\subsection{Quality of the virtual classroom}

In business-to-consumer environments, website quality is a key factor for e-commerce; customers' perceptions of website quality have positive impacts on 


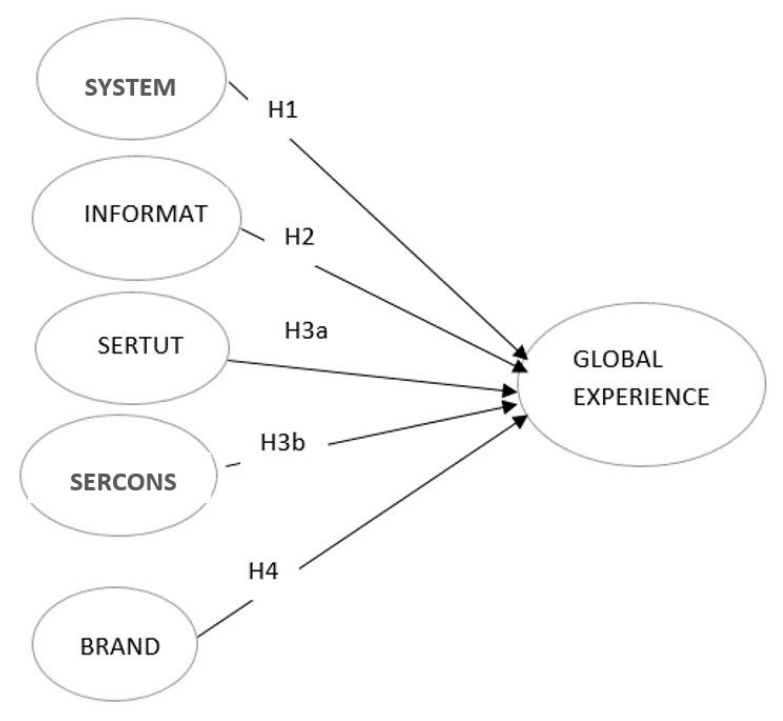

Figure 1. Conceptual model.

their usage intentions (Ajay-Kaushik \& Potti-Srinivasa, 2017; Chang \& Chen, 2008) and also directly affect purchase intentions (Lin, 2007). As Buttle and Marklan (2019) and Chiu, Wang, Fang, and Huang, (2014) point out, the experience of an online customer is conditioned by the quality of the website, which defines the type of relationship the customer can establish with the brand, as well as the outcomes he or she obtains.

Several studies offer measures of website quality, and one that has become relatively widespread is the measure proposed by Lin (2007). According to this model, website quality is a multidimensional construct that includes the quality of the system, the quality of the information, and the quality of the service. This model is appealing, in that it explains quality by adopting a dual approach to both the information system and the customer or user (Wang, 2016). As Yu, Roy, Quazi, and Han (2017) point out, an approach focused on the information system implies that the determinants of customer acceptance are parameters such as website usability systems, accurate information, and transaction security. A customer orientation suggests that the attraction and retention of the customer by the online service provider is central and determined by characteristics of the relationship (Monferrer, SegarraMoliner, Estrada, \& Moliner, 2019; Pansari \& Kumar, 2017). Lin (2007) also suggests that characteristics such as responsiveness, confidence, and empathy shown by the seller are decisive for establishing the quality of the treatment that the customer receives. Both these elements apply to higher education services: the technical characteristics of online classrooms are associated with the system, and the teaching materials correspond to the information. Finally, the quality of the service is determined by the relationship established between the teacher and the students.

With respect to the quality of the system, we highlight that this refers to the technology that facilitates the operation of the virtual classroom, within the virtual learning environment. Elements such as ease of use, web design, and convenience thus determine quality, as perceived by the students (Al-Qeisi, Dennis, Alamanos, \& Jayawardhena, 2014). In turn, interactivity levels might affect students' level of use of the information provided on the website (Kraushaar \& Novak, 2019). The interface also determines some of the attractiveness perceived by the student, thereby conditioning the student's level of interaction with other members of the environment (So, Choi, Lim, \& Xiong, 2012). Students also require feedback and responses from the faculty and staff. Finally, as Kauffman (2015) and Wu, Shen, and Chang (2015) point out, web design and interactivity are fundamental to the success of the virtual learning process. In particular, these two factors affect the level of student satisfaction and students' predisposition to engage in collaborative learning processes. Therefore, we propose the following:

H1. The quality perceived in the system influences the student experience in relation to the university.

The quality of the information is measured as the value that the student receives from the informative contents and didactic resources available in the virtual classroom. Simonson, Zvacek, and Smaldino (2019) highlight which characteristics are most important in determining quality, including updated content, utility, accuracy, and presentation. Studies in the field of e-commerce also note the need to consider aspects related to the security and confidentiality of the information, especially when it comes to customers' personal or financial data (Bandara, Fernando, \& Akter, 2019). In a virtual learning environment, information confidentiality probably pertains more to enrollment data, such as qualifications or grades (Montazer, 2018; Stich \& Reeves, 2017). Overall, Xiao and Wilkins (2015) suggest that the quality of information improves the student-institution relationship, by reducing levels of uncertainty and improving levels of satisfaction. Therefore, we propose the following:

H2. The perceived quality of the information influences the student experience in relation to the university. 
Finally, the service quality dimension is defined as the student's evaluation and judgment of the teaching process (Chong \& Ahmed, 2015). Service quality is a determining factor in students' intentions to enroll in online universities, and Hamari, Hanner, and Koivisto (2017) note that responsiveness, trust, and empathy are critical factors to perceptions of a high-quality service in online environments. Parasuraman, Zeithaml, and Berry $(1985,1988)$ already established the relevance of these factors in face-to-face environments, and Akbar and Mannan (2015) confirm their importance for online services, including education. In this context, the service received by the student is offered by a teacher, who might function more as a tutor-teacher or more as a consultantteacher. A consultant-teacher is responsible for student learning and continuous evaluations of academic progress. A tutor-teacher, in turn, focuses on the curriculum pursued by the student, acting as a mediator between the student and the institution in relation to any process or problem the student has. Both profiles are important. We thus formulate the following research hypotheses:

H3. The quality perceived in the relationship between the student and teacher influences the student experience in relation to the university. Specifically,

H3a. The quality perceived in the relationship between the student and the tutor-teacher influences the student experience in relation to the university.

H3b. quality perceived in the relationship between the student and the consultant-teacher influences the student experience in relation to the university.

\subsection{Valuation of the university brand}

The brand of an academic institution exerts a significant influence on students' behavior. This brand offers protection, but above all, it identifies and differentiates the university from other academic institutions. Karaosmanoglu and Gultekin (2019) suggest that university branding gives graduates a sense of identification and a way to define themselves not merely as customers but as life-long members of the corporate brand community. Because a university is a service industry, Kaushal and Ali (2019) further explain that university branding must reflect the intangibility and inseparability aspects of education services. As a service brand, it requires a greater emphasis on internal marketing, because every employee is a consumer touchpoint, and service brands must help reduce the risk of intangibility. Brands are essential to consumers' social status; one benefit of university education is it bestows a certain status level (Williams \& Omar, 2014).

According to Alraimi, Zo, and Ciganek (2015), the image of a higher education institution is a subjective reflection of the institution's quality, influence, and trustworthiness. Its image is a valuable, intangible asset, which significantly influences students' decision-making processes when choosing a university (James-MacEachern \& Yun, 2017), as well as their initial trust. Through connotations associated with the brand, students obtain a first impression of the university, which facilitates their decision about whether to study there. Pimienta et al. (2016) argue that the student's image of a university evolves over time, linked to a vast system of values and associations that can change more or less. Also, the brand provides relevant information about the behavior of the institution and its ability to deliver on its promises (Dennis, Papagiannidis, Alamanos, \& Bourlakis, 2017). This information is of vital importance for students when deciding whether to remain at the same institution or leave, which determines the consolidation of their relationship.

Jung and Seock (2016) suggest that brand awareness and image are decisive elements in the brand valuation process. They influence decision making even in situations with varying levels of uncertainty, and they also make it possible to develop a relationship based on trust and mutual commitment (Balaji, Roy, \& Sadeque, 2016). Lee, Park, and Cameron (2018) and Patlan-Pérez and Martínez-Torres (2017) suggest that for universities a strong brand image can attract and retain the best students, teachers, and employees. For students, the image of the educational institution is central to their initial choice, growing loyalty, and recommendations to other potential students. For teachers and support staff, this image can enhance performance and productivity, while also generating emotional bonds, commitment, and cohesion between staff and the institution (Lee, 2019; Patlan-Pérez \& Martínez-Torres, 2017).

The brand assessment thus directly influences students' experiences with the institution (Hsieh \& Chang, 2016). The students' expectations of the academic institution involve not only academic results but also the processes and behaviors associated with the relationship as it develops over time. If students perceive that the institution is highly engaged in the relationship and fulfills its commitments satisfactorily, the university will likely meet their expectations well, producing a favorable experience. Therefore, we propose the following: 
H4. The assessment of the university institution's brand has a positive influence on the student experience in relation to the university.

\section{Methodology}

This research used an email survey sent to students enrolled in the different post-graduate programs of a digital university. Of the 2,003 students enrolled in the 2015/2016 academic year, 304 replied to the questionnaire (Table 1), which consisted of six sections on different aspects related to technological applications and information content, as well as the behaviors of tutors and consultants. The students also provided their assessments of the institutional brand.

The study variables are detailed in the Appendix A. These variables reflect the perceived quality of the virtual classroom and the evaluation of the university brand. For the quality of the virtual classroom, we followed Lin (2007) and measured the following: (1) the quality of the system according to the web design and degree of interactivity; (2) the quality of information through information capacity and security; and (3) service quality according to responsiveness, trust, and empathy. Concerning the quality of the system, web design refers to the level of usability, access, convenience, ease of use, and attractiveness that the web platform provides. Interactivity pertains to the capacity of the website user to participate interactively in the process, due to the presence of multimedia tools, such as feedback and multiple response mechanisms.

Regarding the quality of the information, information capacity refers to the ability to inform the user, precisely and efficiently, about services or products available on the website. With regard to resources and educational content, information capacity implies an ability to facilitate learning or improve the student's level of training, given the precision, degree of novelty, or utility of the teaching materials. The second dimension, security, reflects the confidentiality of the student's personal and academic information. For service quality, responsiveness implies the level of utility the student perceives, in terms of responses received from consultants and tutors. Trust indicates perceptions of the credibility of the consultant or tutor. Finally, empathy suggests the ability of the faculty member, whether a tutor or consultant, to understand and respond to the students' needs adequately. Furthermore, the respondents evaluated the university brand based on their experiences as students.

Our survey approach does not enable us to derive a psychographic profile of the sample, in that the surveys of teaching quality could not obtain data related to students' economic situation, household composition, or lifestyles. Instead, the analysis began with an exploratory factor analysis to assess the unidimensionality of the scales. The Bartlett sphericity test produced a $p$-value of 0.000 , thus rejecting the null hypothesis of uncorrelated variables. Factor analysis was therefore deemed appropriate. In addition, the Kaiser-Meyer-Olkin value was close to one. Next, we confirmed the reliability of the scales by calculating the Cronbach's alpha for each dimension and group. The values obtained for all constructs exceeded the value of 0.7 recommended by Nunnally and Bernstein (1994).

The final procedure reflected the recommendations for developing structural models (Hair, Black, Babin, Anderson, \& Tatham, 2006). Specifically, we progressively eliminated, one at a time, items that failed to comply with any of the three criteria proposed by Jöreskog and Sörbom $(1993)^{2}$. In the initial stage, we considered the absence of dimensions for each construct and the totality of the items loaded in a single factor. From the first-order factor analyses for each latent variable, we detected (1) correlations between the errors of the indicators that made up each construct and (2) some Lambda $(\lambda)$ values that were less than 0.5 . Before eliminating these items, though, we applied LM and Wald tests to each construct, so that

\section{Table 1}

\section{Technical details}

\begin{tabular}{ll}
\hline \multicolumn{1}{c}{ Universe } & \multicolumn{1}{c}{ Students of a digital university during the 2015/2016 academic year } \\
\hline Sample unit & Students enrolled in postgraduate programs of the digital university in the second semester of the \\
& $2015 / 2016$ academic year \\
Information collection method & Email with a link to the survey \\
Sampling procedure & Non-probabilistic, convenience method \\
Number of surveys & 304 received, meaning a response rate of $15 \%$ \\
Collection period & July 18-September 10, 2016 \\
\hline
\end{tabular}


we could verify either the existence of another underlying structure or the need for modifications to improve the results obtained.

Each construct was formed of different dimensions, which prompted us to adopt a rival model strategy (Hair et al., 2006). One of the rival models considered was a previously analyzed one, namely a model without dimensions. Ultimately though, the model with different dimensions for each construct emerged as better fitting the data than the initial model. Finally, complementary to the reliability analyses in the exploratory phase, we used two additional criteria to measure the consistency of the proposed scales: the composite reliability of the construct and the average variance extracted (AVE). All the constructs had adequate values according to these measures.

\section{Results}

To validate the structural model in Figure 1, we used partial least squares (PLS) regression and estimated the model in SmartPLS 2.0 (Ringle, Wende, \& Will, 2005). To establish the significance of the parameters, we adopted a bootstrapping method for 304 subsamples, equal in size to the original sample. Moreover, we ensured convergent validity (see Appendix B) by suppressing any indicators whose factor loading was not significant or was

Table 2

\section{Reliability measures}

\begin{tabular}{clcc}
\hline & AVE & $\begin{array}{c}\text { Composite } \\
\text { Reliability }\end{array}$ & Cronbach's $\boldsymbol{\alpha}$ \\
\hline INFORMAT & 0.768 & 0.8690 & 0.7009 \\
BRAND & 0.6847 & 0.8967 & 0.8466 \\
SERCONS & 0.8202 & 0.9319 & 0.8904 \\
SERTUT & 0.8976 & 0.9460 & 0.8864 \\
SYSTEM & 0.8790 & 0.9356 & 0.8629 \\
\hline
\end{tabular}

less than 0.7. The resulting model indicates reliability, in terms of the generally established criteria (Cronbach's alpha, composite reliability, AVE) (Table 2).

To assess discriminant validity, the only criterion that is applicable in PLS is that the AVE for each factor must be greater than the square of the correlation between any other pair of factors (Ab Hamid et al., 2017). This criterion is met, as Table 3 shows.

To assess the predictive capability of the structural model, we applied the criterion proposed by Falk and Millar (1992), such that the R-square values of each dependent construct should be greater than 0.1 . Table 4 details the corresponding values.

The results confirm direct, intense effects of the assessment of the university brand on the experience $(\beta=0.408 ; p<0.01 ; \mathrm{H} 4)$, which is consistent with the prediction that the brand can reduce uncertainty surrounding the intangible nature of the services that students receive. As predicted by Chang and Chen (2008), James-MacEachern and Yun (2017), and Patlan-Pérez and Martínez-Torres (2017), students use the university brand to meet their self-fulfillment or professional development needs by acquiring this service.

We also confirm prior findings related to the quality of the system $(\beta=0.231, p<0.01 ; \mathrm{H} 1)$, in terms of the importance of feedback, interfaces, navigability, and ease of use (Kauffman, 2015; Lin, 2007; Wu et al., 2015). These features of the environment in which the learning process takes place are crucial to student assessments. They also strongly influence the effort and time that individual students dedicate to the learning process, by ensuring the process can be simple, fun, and pleasant, such that they generate positive associations and encourage a positive experience.

The effect of the service provided by consultantteachers $(\beta=0.172 ; p<0.01$; H3b) has a significant influence on student experiences. When the student

Table 3

\section{Discriminant validity}

\begin{tabular}{ccccccc}
\hline & INFORMAT & BRAND & EXPERGL & SERCONS & SERTUT & SYSTEM \\
\hline INFORMAT & $\mathbf{0 . 8 7 6 5}$ & & & & & \\
BRAND & 0.5738 & $\mathbf{0 . 8 2 7 4}$ & & & & \\
EXPERGL & 0.5794 & 0.7347 & N.A & & & \\
SERCONS & 0.5573 & 0.5184 & 0.5470 & $\mathbf{0 . 9 0 5 6}$ & & \\
SERTUT & 0.5161 & 0.5358 & 0.5782 & 0.5252 & $\mathbf{0 . 9 4 7 4}$ & \\
SYSTEM & 0.5680 & 0.6228 & 0.6464 & 0.4766 & 0.4363 & $\mathbf{0 . 9 3 7 5}$ \\
\hline
\end{tabular}

Note:diagonal numbers are the estimated correlations between the factors. The numbers on the diagonal are the square roots of the average variances extracted. 
Table 4

\section{Hypotheses tests}

\begin{tabular}{|c|c|c|c|}
\hline Hypothesis & Standardized $\beta$ & $\begin{array}{c}\text { Bootstrap } \\
\text { t-value }\end{array}$ & $P$ value \\
\hline $\begin{array}{l}\text { H1. The quality perceived in the system influences the student experience in relation } \\
\text { to the university. }\end{array}$ & $0.231^{* * *}$ & 3.0372 & 0.003 \\
\hline $\begin{array}{l}\text { H2. The perceived quality of the information influences the student experience in } \\
\text { relation to the university. }\end{array}$ & $0.073^{\mathrm{NS}}$ & 1.3766 & 0.178 \\
\hline $\begin{array}{l}\text { H3a. The quality perceived in the relationship between the student and the tutor- } \\
\text { teacher influences the student experience in relation to the university. }\end{array}$ & $0.095^{* *}$ & 2.1679 & 0.022 \\
\hline $\begin{array}{l}\text { H3b. The quality perceived in the relationship between the student and the } \\
\text { consultant-teacher influences the student experience in relation to the university. }\end{array}$ & $0.172^{* * *}$ & 3.9095 & 0.000 \\
\hline $\begin{array}{l}\text { H4. The student's assessment of the institution's brand has a positive influence on the } \\
\text { student experience in relation to the university. }\end{array}$ & $0.408^{* * *}$ & 6.2755 & 0.000 \\
\hline
\end{tabular}

Notes: $\mathrm{R}^{2}=0.642 . \mathrm{Q}^{2}=0.617^{\star * \star} . p<.001 ; p<.01{ }^{* \star} p<.05 ;{ }^{\star} p<.10$; ${ }^{\mathrm{NS}}$ not significant.

acquires this service, the goal is to satisfy his or her learning needs, which can only be achieved by teachers who take charge of the teaching-learning process. This variable also contributes to the long-term development of the brand (Patru \& Balaji, 2016), in that excellent human resources (teachers) indicate the quality of universities. The service quality provided by tutor-teachers $(\beta=0.095 ; p<0.01$; $\mathrm{H} 3 \mathrm{a})$ also has an effect, though a weaker one than the other influences we have outlined. Students appreciate a professional, linked to the institution, who can help them define their curricula, guide them, and help them resolve queries or problems associated with administrative and academic procedures (Lee, 2019). However, the effect of the information provided to the student is not significant ( $\beta=0.073, p<0.01 ; \mathrm{H} 2)$, contrary to the findings of Lee (2019). Perhaps the standardization of information (e.g., consistent teaching platforms, similar web designs) and increasing use of platform-based resources provided by universities, which make it easy for students to locate information quickly, reduces the importance of making up-to-date, orderly, and important information available to students, as might universities' efforts to achieve transparency in their information transmission.

\section{Discussion}

Strategic marketing models developed in highly competitive sectors are also useful for managing organizations with a more social and service-oriented purpose. As we show, concepts such as customer experience, with their high relevance for the design of strategic marketing in both physical and online environments, can help in the effective management of academic institutions too.
University education providers must increasingly adopt a student orientation to guarantee their survival and positioning in the market. To adapt their services to the needs of students, universities create digital learning environments. There, new models of teaching and learning are put into practice, where the interaction between the student and other individuals, and with technology, is critical in the student experience.

Following the works of Schmitt and Zarantenello (2013) and Shapiro et al. (2017), we propose that the quality of a virtual classroom, measured in three dimensions (quality of the system, quality of information, and service quality), together with the students' brand assessments, determine their experience as consumers of the service. By analyzing a sample of 306 students of one digital university, we confirm three of the four hypotheses. In particular, the quality of the system, the quality of the service, and evaluations of the brand define students' experiences with the institution. The brand assessment is an essential factor. At the digital university, this finding is mirrored in the high loyalty rates exhibited by the community of students and graduates (over $70 \%$ ), as well as the strong image it has developed as a leader in online education. The university was the first one in the world to offer a totally online education, so it has managed to achieve a reliable reputation linked to innovation and educational quality. All universities should recognize the importance of their brand name at a strategic level. In addition to facilitating their identification, the name of the university acts as a trademark that promotes recognition of the institution.

Further evidence in support of the importance of brand assessments comes from the strong student or 
consumer orientation that permeates the digital university's organizational culture. As an institution that provides distance education, its educational and management model is designed to meet the needs of particular students: those older than 30 years, who seek to reconcile their existing work and personal commitments with their desire to pursue lifelong learning. In addition, most students already have professional careers, so they seek academic training that offers a practical, applied approach. The university's ability to fulfill these promises is critical and depends on its relationship with its current students, as well as its ability to attract new ones. These students are demanding and well informed, with strong purchasing power, but they suffer from time limitations. Accordingly, the credibility of the university is based on students' assessments of its brand, the experience they gain, and their loyalty levels.

The quality of the system, along with the relationship that the student maintains with the virtual campus, is also fundamental to the student's online university experience. Kraushaar and Novak, (2019), Park, (2009) and Simonson et al. (2019) cite three essential barriers to distance learning in online settings. The first two pertain to the technology that supports the service, namely the ease of use and perceived utility. The third reflects the threat of feelings of isolation or loneliness that students might experience during their studies. Thus, students who pursue online learning must have some technological competences; skills that seem natural to a digital native may represent challenges for digital immigrants. Accordingly, students who decide to pursue higher education through an online university must recognize the need to adopt a technology that will exhibit greater or lesser degrees of ease of use and perceived utility.

The experience will be better if the technology that supports the virtual classroom allows for easy navigation and easy, fast, and intuitive access to content, as well as making the process of acquiring knowledge and skills practical, fun, and collaborative. The availability of external multimedia resources and means of communication with other community members can also enhance the student experience. Some sense of accompaniment is vital to reduce the feelings of loneliness and isolation that tend to affect online students; they need to know that they are not alone and that they can count on the help of consultant- and tutor-teachers. The student experience will be better when the academic staff demonstrates strong academic and professional expertise and skills related to the topic area, as well as professional commitment to empathizing with students, understanding their problems, and helping them resolves complex situations.

Recognizing these insights, the digital university has committed to continually renewing its web environment, with the ongoing incorporation of 2.0 tools, to ensure an online environment that supports a direct, forthcoming relationship between students and academic staff. Besides the direct impact of these efforts on the students' experience, they also indirectly influence the image of the university's brand and students' assessments of it. In this sense, they can establish and shape the image of an innovative university that is simultaneously closed and open.

Finally, the quality of the information, and in particular the resources and teaching materials provided, is not a determinant of students' experience with the university. For conventional students who first come in contact with a traditional university environment, the quality of teaching materials is critical to the learning process. But for students who already have the knowledge and relevant work experience in their study area, and who participate in the learning process online, the importance of these resources and teaching materials decreases. These students are aware of their needs, such that they are able to judge the quality of the resources and search for updated resources in the network on their own.

\section{Limitations and Future Research Lines}

The results obtained show the strategic role of the students' experience in academic institutions management. Also, it is shown that it is necessary to identify the elements that influence that experience in order to design effective actions. In the online context, this is fundamental, as universities face the digital challenge by incorporating virtual learning environments.

Although the results obtained can be generalized to the university context, the various limitations of this study must be considered. Firstly, it should be noted that the data correspond to a single digital university, so it is possible that the results are biased by the characteristics of the institution analyzed. On the other hand, the students analyzed are postgraduate students, so it is possible that students from lower levels, and with a different sociodemographic profile, may provide some different results.

The novelty of the subject encourages us to propose future lines of research, such as analyzing different student 
profiles, or comparing between the determining factors of the student experience, in the online and offline contexts.

\section{References}

Ab Hamid, M. R., Sami, W., \& Sidek, M. M. (2017, September). Discriminant validity assessment: Use of Fornell \& Larcker criterion versus HTMT criterion. Journal of Physics: Conference Series, 890(1), p. 012163). IOP Publishing.

Adhikari, A. (2019). Using Sensory Memorabilia to design Experience Product (NBER Working Paper No. 327). Retrieved from https://iimk.ac.in/websiteadmin/ FacultyPublications/Working\%20Papers/3080Final\%20 File\%20For\%20Upload.pdf

Ahn, J., \& Back, K. J. (2018). Antecedents and consequences of customer brand engagement in integrated resorts. International Journal of Hospitality Management, 75, 144-152.

Akbar, A., \& Mannan, A. (2015). The role of online service quality in enhancing customer satisfaction: An empirical investigation of Pakistani Banks. International Journal of Information, Business and Management,7(4), 272.

Ali, F., Amin, M., \& Cobanoglu, C. (2016). An integrated model of service experience, emotions, satisfaction, and price acceptance: an empirical analysis in the Chinese hospitality industry. Journal of Hospitality Marketing \& Management, 25(4), 449-475.

Alraimi, K. M., Zo, H., \& Ciganek, A. P. (2015). Understanding the MOOCs continuance: The role of openness and reputation. Computers \& Education, 80, 28-38.

Al-Qeisi, K., Dennis, C., Alamanos, E., \& Jayawardhena, C. (2014). Website design quality and usage behavior: Unified theory of acceptance and use of technology. Journal of Business Research, 67(11), 2282-2290.

Altbach, P. G., Reisberg, L., \& Rumbley, L. E. (2019). Trends in global higher education: Tracking an academic revolution. Paris France,

Aleixo, A. M., Leal, S., \& Azeiteiro, U. M. (2018). Conceptualization of sustainable higher education institutions, roles, barriers, and challenges for sustainability:
An exploratory study in Portugal. Journal of Cleaner Production, 172, 1664-1673.

Andersson, S., Awuah, G., Aagerup, U., \& Wictor, I. (2020). How do mature born globals create customer value to achieve international growth? International Marketing Review, 37(2), 185-211.

Atulkar, S., \& Kesari, B. (2017). Satisfaction, loyalty and repatronage intentions: Role of hedonic shopping values. Journal of Retailing and Consumer Services, 39, 23-34.

Balaji, M. S., Roy, S. K., \& Sadeque, S. (2016). Antecedents and consequences of university brand identification. Journal of Business Research, 69(8), 3023-3032.

Bandara, R., Fernando, M., \& Akter, S. (2019). Privacy concerns in e-commerce: A taxonomy and a future research agenda. Electronic Markets, 1-19.

Blackston, M., \& Lebar, E. (2015). Constructing consumerbrand relationships to better market and build businesses. Fournier, S., Breazeale, M., Avery, J., Editos. Strong Brands, Strong Relationships. Abingdon, Oxon: Routledge,

Beyari, H., \& Abareshi, A. (2018). Consumer satisfaction in social commerce: an exploration of its antecedents and consequences. The Journal of developing areas, 52(2), 55-72.

Bishop, S. (2018). A Practical Guide for Managers in Using the Customer Experience to Assist in Data-Driven Decision Making for Co-Creative Innovations. In 2018 Engaged Management Scholarship Conference: Philadelphia, PA.

Buttle, F., \& Maklan, S. (2019). Customer relationship management: concepts and technologies. New York: Routledge.

Boustani, G. (2019). Ephemeral Retailing: Pop-upstores in a postmodern consumption Era. Place of Publication: Routledge.

Bowen, G., \& Bowen, R. (2019). Brand trust in offline and online environments: Lessons for social media. In Information Resources Management Association, Brand culture and identity: concepts, methodologies, tools, and applications (pp. 1269-1293). New York: IGI Global.

Bryson, J. M. (2018). Strategic planning for public and nonprofit organizations: A guide to strengthening and sustaining organizational achievement. New Jersey: John Wiley \& Sons. 
Carbone, L., \& Haeckel, S.H. (1994). Engineering customer experiences. Marketing Management, 3(3), 9-11.

Cassidy, S. (2016). Virtual learning environments as mediating factors in student satisfaction with teaching and learning in higher education. Journal of Curriculum and Teaching, 5(1), 113-123.

Cerezo, R., Sánchez-Santillán, M., Paule-Ruiz, M. P., \& Núñez, J. C. (2016). Students' LMS interaction patterns and their relationship with achievement: A case study in higher education. Computers \& Education, 96, 42-54.

Chathoth, P. K., Ungson, G. R., Altinay, L., Chan, E. S., Harrington, R., \& Okumus, F. (2014). Barriers affecting organisational adoption of higher order customer engagement in tourism service interactions. Tourism Management, 42, 181-193.

Chang H. H., \& Chen, S.W. (2008). The impact of online store environment cues on purchase intention: Trust and perceived risk as a mediator, Online Information Review, 32(6), 818-841.

Chong, Y. S., \& Ahmed, P. K. (2015). Student motivation and the 'feel good' factor: An empirical examination of motivational predictors of university service quality evaluation. Studies in Higher Education, 40(1), 158-177.

Datu, J. A. D., \& Mateo, N. J. (2015). Gratitude and life satisfaction among Filipino adolescents: The mediating role of meaning in life. International Journal for the Advancement of Counselling, 37(2), 198-206.

Dennis, C., Papagiannidis, S., Alamanos, E., \& Bourlakis, M. (2017). The role of brand attachment and its antecedents in brand equity in higher education. In M. Stieler (Ed.), Creating marketing magic and innovative future marketing trends (pp. 287-292). Switzerland: Springer, Cham.

Dixon, M. R., Reed, D., Smith, T., Belisle, J., \& Jackson, R. E. (2015). Research ranking of behavior analytic graduate training programs and their faculty. Behavior Analysis in Practice, 8(1), 7-15

Dootson, P., Beatson, A., \& Drennan, J. (2016). Financial institutions using social media-do consumers perceive value?. International Journal of Bank Marketing, 34(1), 9-36.
Ebrahim, R., Ghoneim, A., Irani, Z., \& Fan, Y. (2016). A brand preference and repurchase intention model: The role of consumer experience. Journal of Marketing Management, 32(13-14), 1230-1259.

Elsharnouby, T. H. (2015). Student co-creation behavior in higher education: The role of satisfaction with the university experience. Journal of Marketing for Higher Education, 25(2), 238-262.

Esch, F. R., Möll, T., Schmitt, B., Elger, C. E., Neuhaus, C., \& Weber, B. (2012). Brands on the brain: Do consumers use declarative information or experienced emotions to evaluate brands?. Journal of Consumer Psychology, 22(1), 75-85.

Esharnouby, T. H. (2015). Student co-creation behaviour in higher education: The role of satisfaction with the university experience. Journal of Marketing for Higher Education, 25(2), 238-262.

Falk, R. F., \& Miller, N. B. (1992). A primer for soft modeling. Ohio: University of Akron Press.

Farias, S. A. de, Aguiar, E. C., \& Melo, F. V. S. (2014). Store atmospherics and experiential marketing: A conceptual framework and research propositions for an extraordinary customer experience. International Business Research, 7(2), 897-99.

Fernandes, T., \& Moreira, M. (2019). Consumer brand engagement, satisfaction and brand loyalty: A comparative study between functional and emotional brand relationships. Journal of Product \& Brand Management, 28(2), 274-286.

Frantz, N. B., Pears, E. S., Vaughn, E. D., Ferrell, J. Z., \& Dudley, N. M. (2016). Is John Smith really John Smith? Misrepresentations and misattributions of candidates using social media and social networking sites. In R. N. Landers, G. B. Schimidt (Eds.), Social Media in Employee Selection and Recruitment: Theory, practice, and current challenge (pp. 307-339). Switzerland: Springer, Cham.

Gallarza, M. G., Arteaga, F., \& Gil-Saura, I. (2019). Customer value in tourism and hospitality: Broadening dimensions and stretching the value-satisfaction-loyalty chain. Tourism Management Perspectives, 31, 254-268. 
Garg, R. J., Vandana, \& Kumar, V. (2017, December). Modelling the impact of customer experience on brand loyalty: A conceptual study. Proceedings of ICRBS. Department of Management Studies, IIT Roorkee, 40-46.

Goeser, P. T., Hamza-Lup, F. G., Johnson, W. M., \& Scharfer, D. (2011). VIEW: A virtual interactive webbased learning environment for engineering. Advances in Engineering Education, 2(3), 1-24.

Gómez-Suárez, M., Martínez-Ruiz, M.P., \& MartínezCaraballo, N. (2017). Consumer-brand relationships under the marketing 3.0 paradigm: A literature review. Frontiers in Psychology, 8(252), 1-4.

González-Marcos, A., Alba-Elías, F., Navaridas-Nalda, F., \& Ordieres-Meré, J. (2016). Student evaluation of a virtual experience for project management learning: An empirical study for learning improvement. Computers \& Education, 102, 172-187.

González-Rodríguez, M. R., Domínguez-Quintero, A. M., $\&$ Paddison, B. (2019). The direct and indirect influence of experience quality on satisfaction: the importance of emotions. Current Issues in Tourism, 1-19.

Hair, J. F. Jr., Black, W. C., Babin, B. J., Anderson, R. E., \& Tatham, R. L. (2006). Multivariate Data Analysis, (6 th ed.). New Jersey: Education. Inc., Upper Saddle River.

Hansen, T., Grønholdt, L., Martensen, A., \& Josiassen, A. (2016). Trust in Customer Satisfaction Formation: A Study of Retail Banking in Two Markets. In 19th QMOD-ICQSS International Conference on Quality and Service Sciences. Lund University Press

Hamari, J., Hanner, N., \& Koivisto, J. (2017). Service quality explains why people use freemium services but not if they go premium: An empirical study in free-to-play games. International Journal of Information Management, 37(1), 1449-1459.

Hsieh, S. H., \& Chang, A. (2016). The psychological mechanism of brand Co-creation engagement. Journal of Interactive Marketing, 33, 13-26.

Iglesias, O., Markovic, S., \& Rialp, J. (2019). How does sensory brand experience influence brand equity? Considering the roles of customer satisfaction, customer affective commitment, and employee empathy. Journal of Business Research, 96, 343-354.

Izogo, E. (2017). Customer loyalty in telecom service sector: The role of service quality and customer commitment. The TQM Journal, 29(1), 19-36.

Jain, R., Aagja, J., \& Bagdare, S. (2017). Customer experience: A review and research agenda. Journal of Service Theory and Practice, 27(3), 642-662.

James-MacEachern, M., \& Yun, D. (2017). Exploring factors influencing international students' decision to choose a higher education institution. International Journal of Educational Management, 31(3), 343-363.

Jiménez-Zarco, A. I., Rospigliosi, A., Martínez-Ruiz, M. P., \& Izquierdo-Yusta, A. (2019). Marketing 4.0: Enhancing consumer-brand engagement through big data analysis. In Information Resources Management Association, Web services: Concepts, methodologies, tools, and applications (pp. 2172-2195). Hershey: IGI Global.

Jöreskog, K. G., \& Sörbom, D. (1993). LISREL 8: Structural equation modeling with the SIMPLIS command language.USA: Scientific Software International.

Jung, N. Y., \& Seock, Y. K. (2016). The impact of corporate reputation on brand attitude and purchase intention. Fashion and Textiles, 3(1), 20.

Kahn, B. E., Inman, J. J., \& Verhoef, P. C. (2018). Introduction to special issue: Consumer response to the evolving retailing landscape. Journal of the Association for Consumer Research, 3(3), 255-259.

Kaushal, V., \& Ali, N. (2019). University reputation, brand attachment and brand personality as antecedents of student loyalty: A study in higher education context. Corporate Reputation Review, 1-13.

Kaushik, N., \& Potti-Srinivasa, R. (2017). Effect of website quality on customer satisfaction and purchase intention in online travel ticket booking websites. Management, 7(5), 168-173.

Kauffman, H. (2015). A review of predictive factors of student success in and satisfaction with online learning. Research in Learning Technology, 23, 1-13. 
Karaosmanoglu, E., \& Gultekin, G. (2019). Corporate brand communication in higher education. In B. Nguyen, T. C. Melewar, J. Hemsley-Brown, Strategic Brand Management in Higher Education. New York: Routledge.

Kim, R. B., Matsui, T., Park, Y. J., \& Okutani, T. (2019). Perceived consumer value of omni-channel service attributes in Japan and Korea. Engineering Economics, 30(5), 621-630.

Kraushaar, J. M., \& Novak, D. C. (2019). Examining the effects of student multitasking with laptops during the lecture. Journal of Information Systems Education, 21(2), 241-251.

Lakdawalla, D. N., Doshi, J. A., Garrison Jr, L. P., Phelps, C. E., Basu, A., \& Danzon, P. M. (2018). Defining elements of value in health care-a health economics approach: an ISPOR Special Task Force report [3]. Value in Health, 21(2), 131-139.Lewis, I. (2018). The student experience of higher education (Vol. 16). Routledge.

Leckie, C., Nyadzayo, M. W., \& Johnson, L. W. (2016). Antecedents of consumer brand engagement and brand loyalty. Journal of Marketing Management, 32(5-6), 558-578.

Lemon, K. N., \& Verhoef, P.C. (2016). Understanding customer experience throughout the customer journey. Journal of Marketing, 80(6), 69-96.

Lee, A. (2019). Successful research supervision: Advising students doing research. New York: Routledge.

Lee, Y., Park, H., \& Cameron, G. T. (2018). Strategic communication in US higher education: Testing congruity effects of university identity and image among parents of prospective students. International Journal of Strategic Communication, 12(3), 308-327.

Liu, X., Burns, A. C., \& Hou, Y. (2017). An investigation of brand-related user-generated content on Twitter. Journal of Advertising, 46(2), 236-247.

Lin, H. F. (2007). The impact of website quality dimensions on customer satisfaction in the B2C e-commerce context. Total Quality Management and Business Excellence, 18(4), 363-378.

Mahdi, O. R., Nassar, I. A., \& Almsafir, M. K. (2019). Knowledge management processes and sustainable competitive advantage: An empirical examination in private universities. Journal of Business Research, 94, 320-334.

Marris, P. (2018). The experience of higher education (Vol. 17). Routledge.

Merz, M. A., Zarantonello, L., \& Grappi, S. (2018). How valuable are your customers in the brand value co-creation process? The development of a Customer Co-Creation Value (CCCV) scale. Journal of Business Research, 82, 79-89.

Monferrer, D., Segarra-Moliner, J. R., Estrada, M., \& Moliner, M. A. (2019). Service quality and customer loyalty in a post-crisis context. Prediction-oriented modeling to enhance the particular importance of a social and sustainable approach. Sustainability, 11(18), 4930.

Montazer, G. A. (2018). University website quality improvement using intuitionistic fuzzy preference ranking model. Quarterly Journal of Iranian Distance Education, 1(2), 9-30.

Moorhouse, N., Dieck, M. C. tom, \& Jung, T. (2018). Technological innovations transforming the consumer retail experience: A review of literature. In T. Jung., M. C. tom Dieck, \& P. A. Rauschnabel, Augmented reality and virtual reality (pp. 133-143). Switzerland Springer, Cham.

Munoz-Arcentales, A., Montoya, A., Chalen, M., \& Velásquez, W. (2018, January). Improve customer experience based on recommendation and detection of a pattern change in eating habits. Annual Computing and Communication Workshop and Conference (CCWC), Las Vegas, Nevada, EUA, 8. Retrieved from https://ieeexplore. ieee.org/document/8301622

Nunnally, J. C., \& Bernstein, I. H. (1994). Psychometric theory (3rd ed.). New York, NY: McGraw-Hill.

Osborne, S. P. (2018). From public service-dominant logic to public service logic: Are public service organizations capable of co-production and value co-creation? Public Management Review, 20(2), 225-231.

Pansari, A., \& Kumar, V. (2017). Customer engagement: The construct, antecedents, and consequences. Journal of the Academy of Marketing Science, 45(3), 294-311. 
Park, S. K. (2019). Learning together: Confucius and Freire collaborate to redefine a community of learning. In C. N. Stevenson \& J. C. Bauer (Eds.), Enriching collaboration and communication in online learning communities (pp. 240-257). Hershey: IGI Global.

Parasuraman, A., Berry, L., \& Zeithaml, V. A. (1988): SERVQUAL. A Multiple-Item Scale for Measuring Consumer Perceptions of Service Quality. Journal of Retailing, (64), 12-40.

Parasuraman, A., Zeithaml, V., \& Berry, L. (1985). A conceptual model of service quality and its implications for future research. Journal of Retailing, 49, 44-60.

Patru, M., \& Balaji, V. (Ed.). (2016). Making sense of MOOCs: A Guide for policy-makers in developing countries. Paris: United Nations Educational, Scientific and Cultural Organization (UNESCO).

Patlan-Pérez, J., \& Martín-Torres, E. (2017). Evaluación de la imagen organizacional universitaria en una institución de educación superior. Contaduría y Administración, 62(1), 105-122.

Peters, M. A., \& Besley, T. (2006). Building knowledge cultures: Education and development in the age of knowledge capitalism (Vol. 2). Lanham: Rowman \& Littlefield Publishers.

Pimienta, M. L., Barzola, M. L., \& Zurdo, F. H. (2016). La imagen de las universidades en Mendoza: Percepciones, expectativas y significación de su rol actual. Diálogos Pedagógicos, 13(26), 62-87.

Pine, B. J., \& Gilmore, J. H. (1998). Welcome to the experience economy. Harvard business review, 76, 97-105.

Pucciarelli, F., \& Kaplan, A. (2016). Competition and strategy in higher education: Managing complexity and uncertainty. Business Horizons, 59(3), 311-320.

Riivits-Arkonsuo, I., Kaljund, K., \& Leppiman, A. (2015). Consumer journey from first experience to brand evangelism. Research in economics and business: Central and eastern Europe, 6(1), 5-28.

Ringle, C. M., Wende, S., \& Will, A. (2005). Customer segmentation with FIMIX-PLS. Proceedings of PLS-05 International Symposium, Paris, France, 5.
Simonson, M., Zvacek, S. M., \& Smaldino, S. (2019). Teaching and learning at a distance: Foundations of distance education (7th ed.). Charlotte: IAP.

Sina, A. S., \& Kim, H. Y. (2019). Enhancing consumer satisfaction and retail patronage through brand experience, cognitive pleasure, and shopping enjoyment: A comparison between lifestyle and product-centric displays. Journal of Global Fashion Marketing, 10(2), 129-144.

So, H. J., Choi, H., Lim, W. Y., \& Xiong, Y. (2012). Little experience with ICT: Are they really the next generation student-teachers? Computers \& Education, 59(4), 1234-1245.

Shapiro, H. B., Lee, C. H., Roth, N. E. W., Li, K., ÇetinkayaRundel, M., \& Canelas, D. A. (2017). Understanding the massive open online course (MOOC) student experience: An examination of attitudes, motivations, and barriers. Computers \& Education, 110, 35-50.

Shaw, T. (2018). Student perceptions of service-learning efficacy in a hybrid I online undergraduate writing class. Transformative Dialogues: Teaching \& Learning Journal, 11(2), 1-16

Schmitt, B., \& Zarantonello, L. (2013). Consumer experience and experiential marketing: A critical review. In N. K. Malhotra, Review of Marketing Research (Série RMR. Vol.10): Bingley: Emerald Group Publishing Limited.

Smith, J. L. (2019). Customer-focus environment. Quality Magazine, 58(8), 8-8.

Smilansky, S. (2017). Experiential marketing: A practical guide to interactive brand experiences. New York: Kogan Page Publishers.

Srivastava, M., \& Kaul, D. (2016). Exploring the link between customer experience-loyalty-consumer spend. Journal of Retailing and Consumer Services, 31, 277-286.

Stich, A. E., \& Reeves, T. D. (2017). Massive open online courses and underserved students in the United States. The Internet and Higher Education, 32, 58-71.

Tsaur, S-H., Chiu, Y-T., \& Wang, C-H. (2006). The visitors behavioral consequences of experiential marketing: An empirical study on Taipei Zoo. Journal of Travel and Tourism Marketing 21(1), 47-64. 
Tsay, C. H. H., Kofinas, A., \& Luo, J. (2018). Enhancing student learning experience with technology-mediated gamification: An empirical study. Computers \& Education, 121, 1-17.

Tukker, A., \& Tischner, U. (Eds.). (2017). New business for old Europe: Product-service development, competitiveness and sustainability. Sheffield: Routledge.

Vargo, S. L., \& Lusch, R. F. (2014). Inversions of servicedominant logic. Marketing Theory, 14(3), 239-248.

Vargo, S. L., \& Lusch, R. F. (2017). Service-dominant logic 2025. International Journal of Research in Marketing, 34(1), 46-67.

Vuopala, E., Hyvönen, P., \& Järvelä, S. (2016). Interaction forms in successful collaborative learning in virtual learning environments. Active Learning in Higher Education, 17(1), 25-38.

Wang, E. S. T. (2016). The moderating role of consumer characteristics in the relationship between website quality and perceived usefulness. International Journal of Retail \& Distribution Management, 44(6), 627-639.

Wei, W., Torres, E., \& Hua, N. (2016). Improving consumer commitment through the integration of self-service technologies: A transcendent consumer experience perspective. International Journal of Hospitality Management, 59, 105-115.
Williams, R. L. Jr., \& Omar, M. (2014). Applying brand management to higher education through the use of the brand flux model- the case of Acadia University. Journal of Marketing for Higher Education 24(2), 222-242.

Wu, Y. C. J., Shen, J. P., \& Chang, C. L. (2015). Electronic service quality of Facebook social commerce and collaborative learning. Computers in Human Behavior, 51, 1395-1402.

Xiao, J., \& Wilkins, S. (2015). The effects of lecturer commitment on student perceptions of teaching quality and student satisfaction in Chinese higher education. Journal of Higher Education Policy and Management, 37(1), 98-110.

Yachin, J. M. (2018). The 'customer journey': Learning from customers in tourism experience encounters. Tourism management perspectives, 28, 201-210.

Yu, X., Roy, S. K., Quazi, A., \& Han, Y. (2017). Internet entrepreneurship and "the sharing of information" in an internet-of-things context: The role of interactivity, stickiness, e-satisfaction and word-of-mouth in online SMEs' websites. Internet Research, 27(1), 74-96.

Zomerdijk, L. G., \& Voss, C. A. (2010). Service design for experience-centric services. Journal of service research, 13(1), 67-82. 


\section{Appendix A Study Variables}

\begin{tabular}{|c|c|c|c|}
\hline & Variable & Dimension & \\
\hline Assessment of learnir & s and teaching materials & System Quality (SYSTEM) & Likert $1-5$ \\
\hline Assessment of the vir & om & & \\
\hline Assessment of comm & in the virtual classroom & & \\
\hline $\begin{array}{l}\text { Assessment of the } \mathrm{m} \\
\text { (chats, wikis, forums }\end{array}$ & mmunicative resources of the classroom & & \\
\hline Assessment of studer & & & \\
\hline Organization of learı & ials and resources & Information Quality (INFORMAT) & Likert $1-5$ \\
\hline Influence of learning & on the assimilation of knowledge & & \\
\hline Level of updating of & sources & & \\
\hline $\begin{array}{l}\text { Possibility of using a } \\
\text { classroom space }\end{array}$ & ternal sources of information in the & & \\
\hline Level of fit of the inf & fffered to the student's needs & & \\
\hline Information is treate & ousness & & \\
\hline Tutor teacher & $\begin{array}{l}\text { The tutor teacher teaches me in an } \\
\text { appropriate way }\end{array}$ & Quality of service Tutor (SERTUT) & Likert $1-5$ \\
\hline & The tutor teacher responds clearly & & \\
\hline & $\begin{array}{l}\text { The tutor teacher accompanies the } \\
\text { student }\end{array}$ & & \\
\hline & $\begin{array}{l}\text { The tutor teacher encourages me to } \\
\text { keep the pace of study }\end{array}$ & & \\
\hline Consultant teacher & $\begin{array}{l}\text { The consultant teacher masters the } \\
\text { subject }\end{array}$ & $\begin{array}{l}\text { Quality of service Consultant } \\
\text { (SERCONS) }\end{array}$ & Likert $1-5$ \\
\hline & $\begin{array}{l}\text { The consultant teacher has adequately } \\
\text { planned the learning }\end{array}$ & & \\
\hline & $\begin{array}{l}\text { The consultant teacher responds } \\
\text { within an appropriate timeframe }\end{array}$ & & \\
\hline & $\begin{array}{l}\text { The consultant teacher offers } \\
\text { personalized treatment }\end{array}$ & & \\
\hline The digital university & my skills in virtual environments & Brand university rating (BRAND) & Likert $1-5$ \\
\hline $\begin{array}{l}\text { I take a positive view } \\
\text { university }\end{array}$ & ification offered by the digital & & \\
\hline The digital university & to interact with people in my area & & \\
\hline I feel I am a membc & ital university community & & \\
\hline
\end{tabular}


Appendix B

Reliability and Convergent Validity

\begin{tabular}{|c|c|c|c|c|}
\hline Factor & DIMENSION & Indicator & Loading & T Value \\
\hline \multirow[t]{5}{*}{ Information Quality } & INFOR1 & INFORMATI1 & .79 & 16.01 \\
\hline & & INFORMATI2 & .89 & 17.03 \\
\hline & & INFORMATI3 & .89 & 17.12 \\
\hline & INFOR2 & SECURI1 & .99 & 24.89 \\
\hline & & SECURI2 & .58 & 6.47 \\
\hline \multirow[t]{6}{*}{ System Quality } & SYST1 & WEBDESG1 & .85 & 18.24 \\
\hline & & WEBDESG2 & .84 & 18.67 \\
\hline & & WEBDESG3 & .96 & 23.88 \\
\hline & & WEBDESG4 & .85 & 19.35 \\
\hline & SYST2 & INTERACT1 & .93 & 25.63 \\
\hline & & INTERACT2 & .93 & 25.28 \\
\hline \multirow[t]{7}{*}{ Tutor Service Quality } & SERTUT1 & RESPONS1 & .98 & 16.71 \\
\hline & & RESPONS2 & .89 & 18.49 \\
\hline & SERTUT2 & TRUST1 & .88 & 17.54 \\
\hline & & TRUST2 & .92 & 20.62 \\
\hline & SERTUT3 & EMPATH1 & .93 & 22.12 \\
\hline & & ЕMРАТН2 & .82 & 20.20 \\
\hline & & ЕMРАТН3 & .73 & 15.32 \\
\hline \multirow[t]{6}{*}{ Consultant Service Quality } & SERCONS1 & RESPONS1 & .71 & 13.84 \\
\hline & & RESPONS2 & .74 & 15.85 \\
\hline & & EMPATH1 & .80 & 12.69 \\
\hline & & EMPATH2 & .91 & 14.32 \\
\hline & SERCONS2 & TRUST1 & .89 & 15.23 \\
\hline & & TRUST2 & .93 & 23.62 \\
\hline \multirow[t]{4}{*}{ University Brand } & BRAND & BRAND1 & .68 & 12.11 \\
\hline & & BRAND2 & .72 & 12.90 \\
\hline & & BRAND3 & .80 & 14.86 \\
\hline & & BRAND4 & .78 & 14.54 \\
\hline
\end{tabular}




\section{Conflicts of interest:}

The authors have no conflict of interest to declare

\section{Copyrights:}

RBGN owns the copyrights of this published content

\section{Plagiarism analysis}

RBGN performs plagiarism analysis on all its articles at the time of submission and after approval of the manuscript using the iThenticate tool.

\section{Authors:}

1. Alicia Izquierdo-Yusta, Associate Professor, University of Burgos, Burgos, Spain.

E-mail: aliciaiz@ubu.es

2. Ana I. Jimenez-Zarco, Associate Professor, Open University of Catalunya, Barcelona, Spain.

E-mail: ajimenezz@uoc.edu

3. Maria Pilar Martinez-Ruiz, Full Professor, University of Castilla la Mancha, Albacete, Spain.

E-mail: mariapilar.martinez@uclm.es

4. Inés Gonzalez-Gonzalez, Associate Professor, International University of La Rioja, Logroño, Spain.

E-mail: ines.gonzlaez@unir.net

\section{Authors' Contributions}

1. Alicia Izquierdo-Yusta: Definition of research problem; Development of hypotheses or research questions (empirical studies); Theoretical foundation/literature review; Statistical analysis; Analysis and interpretation of data; Critical revision of the manuscript; Manuscript writing.

2. Ana I. Jimenez-Zarco: Development of hypotheses or research questions (empirical studies); Theoretical foundation/ literature review; Statistical analysis; Analysis and interpretation of data; Critical revision of the manuscript; Manuscript writing.

3. Maria Pilar Martinez-Ruiz: Definition of research problem; Development of hypotheses or research questions (empirical studies); Definition of methodological procedures; Analysis and interpretation of data; Critical revision of the manuscript. 4. Inés Gonzalez-Gonzalez: Development of hypotheses or research questions (empirical studies); Theoretical foundation/ literature review; Analysis and interpretation of data; Critical revision of the manuscript. 